\title{
EFFECT OF ADDED ROCK PHOSPHATE AND COMPOST ON SOIL PHOSPHORUS FRACTIONS AFTER DIFFERENT INCUBATION PERIODS
}

\author{
S. A. Radwan(1), M. M. H. Shalaby(1), W. A. Nada(1), Soad M. EL-Ashry(2), \\ M. A. Abo Seeda ${ }^{(2)}$ and Noha A. El Sisi( ${ }^{(1)}$ \\ (1) Faculty of Agriculture, Menoufia University \\ (2) National Research Centre, Dokki, Cairo, Egypt
}

Received: Jul. 25, 2020

Accepted: Sep. 13,2020

\begin{abstract}
Surface clay Soil samples were collected from EL Hamoul, Kafr El-Sheikh governorate and air dried. Each of plastic pot from the experiment pots was filled with $\mathbf{5 0 0}$ grams from these samples. Three rates from rock phosphate $(0,1$ and $3 \%)$ and three from compost $(0,2$, and $4 \%)$ were added to and mixed with these experiment soil samples in the pots and incubated in three periods ( 0,30 and 90 days) in the lab condition. This experiment was arranged in three replicates using a completely randomized block design. Samples from these applications were taken after each of the three incubation periods. Phosphorus fractions were measured in the taken samples according to Hedley sequential fractionation scheme. The determined P fractions were: (1) $\mathrm{P}_{-} \mathrm{NaHCO}_{3}$, (2) P-NaOH, (3) P$\mathrm{HCl} / \mathrm{H}_{2} \mathrm{SO}_{4}$, (4) P-residual and (5) Total P. Obtained results could be summarized as follows.

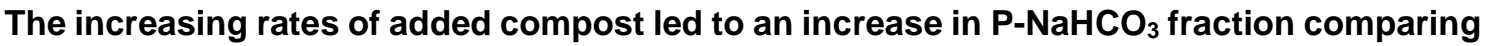
with control treatment. While the increasing rates of added rock phosphate led to a decrease in this fraction and gave the lowest value. The addition of compost and rock phosphate together led to increase in $\mathrm{P}-\mathrm{NaHCO}_{3}$ fraction more than each of them alone. The increase of the incubation period led to an unnoticeable and insignificant decrease in this fraction of phosphorous. $\mathrm{P}-\mathrm{NaOH}$ fraction represents $2.8 \%$ of the total phosphorous. $\mathrm{P}-\mathrm{HCl} / \mathrm{H}_{2} \mathrm{SO}_{4}$ fraction increased with increasing incubation periods, phosphate rock and compost were. The residual $\mathbf{P}$ fraction was decreased with increasing incubation period.
\end{abstract}

Key words: Phosphorus fractions, rock phosphate, compost, incubation periods .

\section{INTRODUCTION}

Phosphorus is a key nutrient element for the growth and development of crops. It is a key element in universal biogeochemical cycles. Phosphorus occurs mainly in hydroxy-apatite $\left\{\mathrm{Ca}_{5}\left(\mathrm{PO}_{4}\right)_{3}(\mathrm{OH})\right\}$ and fluoro-apatite $\left\{\mathrm{Ca}_{10}\left(\mathrm{PO}_{4}\right)_{6} \mathrm{~F}_{2}\right\}$, as orthophosphate. The solubility of $P$ is controlled by Fe (III), AI (III) and Ca. The influence of the solid phase, whether as a suspended particles or sediments, is of considerable importance in regulating the dissolved $P$ phase of natural waters systems. Sediments properties, such as $\mathrm{pH}$ and redox potential could have caused significant variation of phosphorus release potential (Gao et al., 2005), beside mineral-water equilibrium, sorption processes, organisms (bioturbation) and bottom sediment characteristics.

It is worth mentioning that, fertilization became expensive. Therefore, it is necessary to consider the use of some natural rocks such as feldspar, rock phosphate especially with acid treatment for easing the release of elements contained in these materials. Phosphorus is provided mainly by soil, however, it can easily be immobilized in it, and the seasonal application rate of phosphate fertilizer for crops is only $\mathbf{1 0 - 2 5 \%}$. (Liu et al., 2012).

The rock phosphate (RP) could be used as a direct application fertilizer with or 
without other amendments. The utilization of RP is more suitable than the manufacturing phosphoric acid and other soluble fertilizers such as single superphosphate (SSP) or triple one (TSP). Rock Phosphate is a natural mineral fertilizer requiring minimum processing and environmentally benign. It could be more efficient than soluble fertilizers in terms of recovery of phosphate by plants, even for short term crops in soils where the soluble $P$ is readily leached, as in sandy soils and also, possibly for longterm crops in other soils (Rajan et al., 1994). Application of rock phosphates in arid and semi-arid regions is not common, because of its low availability in most of their soils that having alkaline reaction with relatively high $\mathrm{pH}$ and low organic matter.

In many studies, humic and fulvic acids preparations were reported to increase the uptake of mineral elements to promote the root length and to increase the fresh and dry weights of crop plants (Chen et al., 2004). Due to the positive effect of humic substances on the visible growth of plants, these chemicals have been widely used by the growers instead of other substances. Composting organic materials with rock phosphate (RP) has been shown to enhance the solubility of $P$ from RP and is practiced widely as a lowinput technology to improve the fertilizer value of manures (Ibrahim et al., 2008).

This work aims to study the effect of added organic substances (compost) and rock phosphate after different incubation periods on phosphorus forms in the studied soil.

\section{MATERIALS AND METHODS}

Soil samples were collected from the surface layer of a farm located at El Hamoul, Kafr El-Shikh governorate. The collected soil samples were air dried and ground to pass through $2 \mathrm{~mm}$ thieve. Some physiochemical properties for this soil were analyzed according to Burt (2004) and presented in Table (1). Some main minerals contents of added rock phosphate are presented in Table (2). Some physiochemical properties of added compost are shown in Table (3).

Table (1): Some properties for the studied soil.

\begin{tabular}{|c|c|c|c|c|c|c|c|}
\hline \multicolumn{3}{|c|}{ Particle size distribution \% } & \multirow{2}{*}{$\begin{array}{c}\text { Texture } \\
\text { class }\end{array}$} & \multirow{2}{*}{$\begin{array}{c}\text { PH } \\
(1: 2.5)\end{array}$} & \multirow{2}{*}{$\begin{array}{c}\text { EC (1:5) } \\
\text { dSm-1 }\end{array}$} & \multirow{2}{*}{$\begin{array}{l}\text { OM } \\
\%\end{array}$} & \multirow{2}{*}{$\begin{array}{c}\text { CEC } \\
\text { Meq/1oog }\end{array}$} \\
\hline Sand & Silt & Clay & & & & & \\
\hline 31.11 & 8.02 & 60.87 & Clay & 7.6 & 1.8 & 2.01 & 39.7 \\
\hline
\end{tabular}

Table (2): Total $\mathrm{P}_{2} \mathrm{O}_{5}$ in the added Rock Phosphate.

\begin{tabular}{|l|l|}
\hline Total $\mathrm{P}_{2} \mathrm{O}_{5} \%$ & 20.35 \\
\hline
\end{tabular}

Table (3): Some properties for the added compost.

\begin{tabular}{|c|c|c|c|c|c|c|c|}
\hline $\begin{array}{c}\text { EC (1:10) } \\
\text { dSm-1 }\end{array}$ & $\begin{array}{c}\mathrm{PH} \\
(1: 10)\end{array}$ & $\begin{array}{c}\text { OC } \\
\%\end{array}$ & $\begin{array}{c}\mathrm{C} / \mathrm{N} \\
\text { ratio }\end{array}$ & $\begin{array}{c}\mathrm{BD}^{*} \\
\mathrm{gcm}-3\end{array}$ & $\begin{array}{c}\text { Moisture } \\
\%\end{array}$ & $\begin{array}{c}\text { Ash } \\
\%\end{array}$ & $\begin{array}{c}\text { WHC** } \\
\%\end{array}$ \\
\hline 10.5 & 8.6 & 35 & 12.6 & 0.35 & 11.8 & 42 & 160 \\
\hline
\end{tabular}

$\mathrm{BD}^{\star}=$ Bulk density, WHC: Water holding capacity. 
A plastic pot (with $20 \mathrm{~cm}$ inter diameter and $30 \mathrm{~cm}$ height) were filled with $500 \mathrm{~g}$ of prepared fine earth. The added rock phosphate rates were 0,1 and $3 \%$. The added compost rates were 0,2 and $4 \%$. These additives were good mixed with soil samples in the pots and prepared for 3 incubation periods namely 0,90 and 180 days. This experiment was arranged by 81 unites having 27 treatments in three replicates using a completely randomized block design. The treated soil samples in pots were moisten at $60 \%$ of water holding capacity under the laboratory condition during the experiment. Samples were taken from the different treatments after each incubation periods to determine the fractionations of phosphorus.

Hedley sequential fractionations scheme was applied to estimate the fractionations of phosphorus in the tested soil samples according to Sui et al. (1999). The obtained data were statistically analyzed by ANOVA according to Gomez and Gomez (1984).

\section{RESULTS AND DISCUSSION}

The estimated different phosphorus fractions in the studied soil after different treatments with rock phosphate, compost and incubation periods are presented In Table (4). The effect of these treatments with their different rates could be discussed as follows.

Effect of treatments on total phosphorus fraction:

Data in Table (4) showed that, the values of total phosphorus (TP) were varied widely between different treatments and rates. The lowest total phosphorus (TP) value was obtained in the soil without any additives (0treatments at the first incubation period). The highest TP value was obtained with the addition of $1 \% \mathrm{RP}$ and $4 \%$ compost at the longest incubation period. The difference between TP mean values resulted from PR and compost treatments were significant especially between phosphate rock treatments. While the differences between these values that affected by incubation periods were insignificant.

In this respect Shaheen et al. (2007) established that, the values of total $P$ were differed widely between Burullus Lagoon soils depending on the type of deposits and their physiochemical properties. Where the total $P$ was negatively correlated to sand content and positively correlated to silt and clay content. Thus, $P$ is probably associated with the finer soil fractions as it previously reported by (McCullum, 1996).

The relationship between TP $\mathrm{mg} \cdot \mathrm{Kg}^{-1}$ and added rock phosphate rate $\%$ and can be expressed by the following equation:

$$
\mathrm{TP}=2247+934.4 \mathrm{RP} \quad\left(\mathrm{R}^{2}=0.94\right)
$$

This equation exposed that, the increasing TP rate was $934.4 \mathrm{mg} \cdot \mathrm{Kg}^{-1}$ when RP added with $1 \%$. The effect of added compost (\%) on TP can be expressed by the following equation:

$$
\mathrm{TP}=2814+339.5 \text { Compost }\left(R^{2}=0.96\right)
$$

This equation showed that TP increased by rate of $339.5 \mathrm{mg} . \mathrm{Kg}^{-1}$ after 1 $\%$ compost addition. The relationships between TP and incubation periods can be expressed by the following equation:

$$
\mathrm{TP}=3311+60.71^{\text {st }} . \mathrm{P} \quad\left(\mathrm{R}^{2}=0.67\right)
$$

This equation explain that, the TP increased by $60.7 \mathrm{mg} \cdot \mathrm{Kg}^{-1}$ after one month incubation period.

\section{Effect of treatments on other phosphorus fractions}

Data in Table (4) showed that, the phosphorous fractions extracted from the soil can be arranged as follows:

$\mathrm{P}-\mathrm{HCl} / \mathrm{H}_{2} \mathrm{SO}_{4}>\mathrm{P}$-digested > $\mathrm{P}-\mathrm{NaHCO}_{3}>$ P. NaOH 


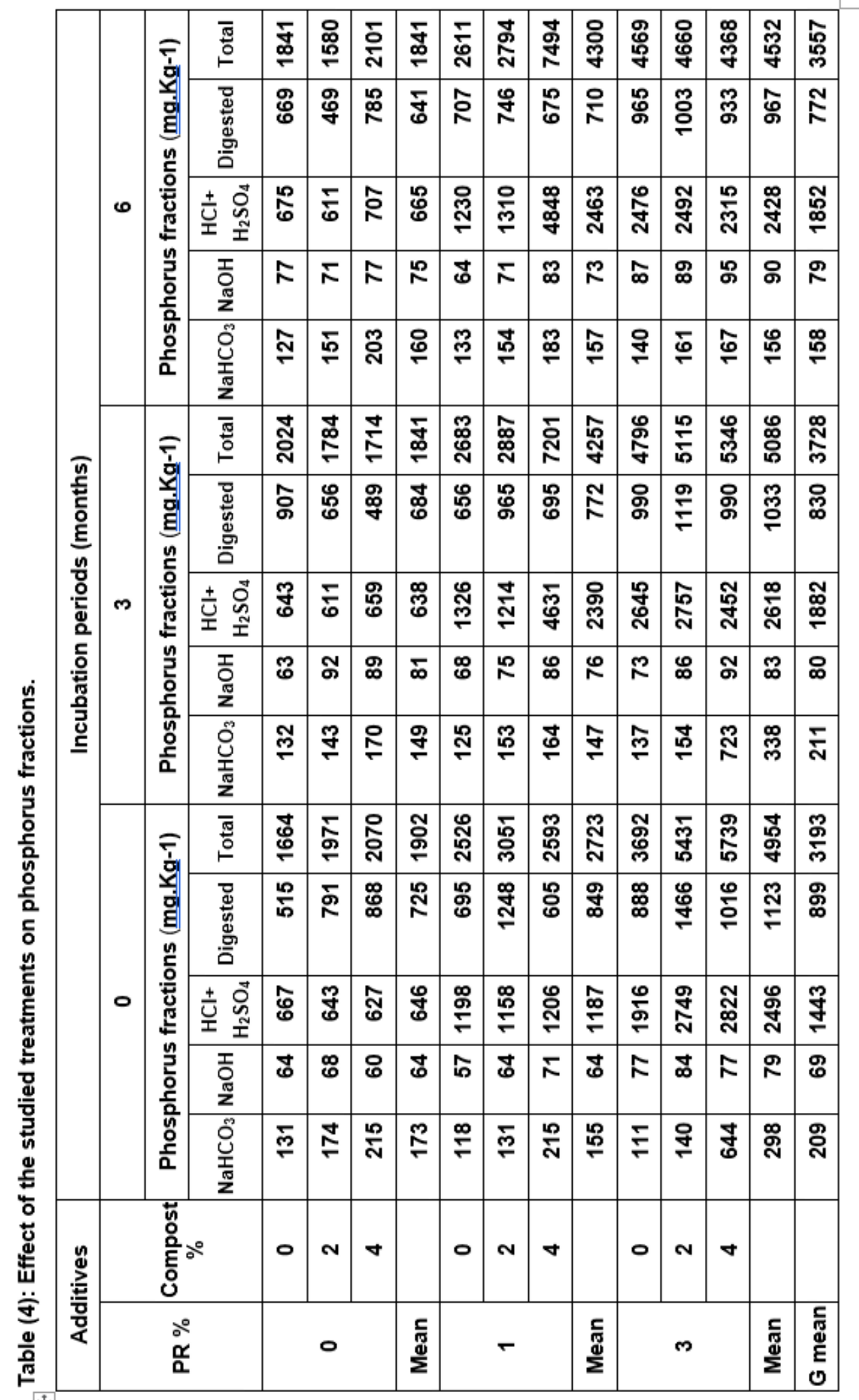


The obtained results indicated that, $P$ $\mathrm{HCl} / \mathrm{H}_{2} \mathrm{SO}_{4}$ is the highest $P$ fraction at all incubation periods, while the lowest fraction was $\mathrm{P}-\mathrm{NaOH}$. The highest values of $\mathrm{P}-\mathrm{HCl} / \mathrm{H}_{2} \mathrm{SO}_{4}$ fraction was found after 3 months incubation period followed by 6 months period. Also, the largest values of $\mathrm{P}-\mathrm{NaHCO}_{3}$ form was obtained after three months. whereas the largest amounts of P-digest fraction was obtained in soil without incubation.

On the other hand, data in Table (4) showed that, most of $P$ fractions was increased with increasing the added rates of RP and compost. Which, the increasing rate of added compost led to increase in $\mathrm{P}_{-} \mathrm{NaHCO}_{3}$ fraction. While the increasing addition of rock phosphate led to a decrease in this fraction and gave the lowest values. Moreover, the addition of compost together with rock phosphate led to a clear increase in $\mathrm{P}-\mathrm{NaHCO}_{3}$ fraction more than each of them alone. While, the increase of the incubation period led to a decrease of this $P$ part.

Al-Oud (2011) found that, the availability of phosphorus was significantly increased in calcareous soil treated with rock phosphate and different rates of organic manure.

Several studies found that, the addition of organic amendments such as compost led to increase of the available phosphorus in soil (Scherer \& Sharma, 2002; Qian \& Schoenau, 2000). There are a direct and indirect positive effect for the addition of compost. The direct positive effect could be ascribed to the phosphorus released from compost. The indirect effect could be returned to the production and release of organic acids and stimulation of microbial activity that can decrease the soil ph. This effect could be led to increasing the release and mobilization of phosphorus in soil (Ayaga et al., 2006; Fuentes et al., 2006; and Khan and Joergensen, 2009).
The following equation can express the relationship between PR $\%$ and $P$ $\mathrm{NaHCO}_{3}$ :

$$
\text { P- } \mathrm{NaCO}_{3}=142.62+37.47 \text { PR (\%) } \quad\left(R^{2}=0.85\right)
$$

This equation pointed out that, the rate of increment in $\mathrm{P}^{-\mathrm{NaHCO}_{3}}$ fraction was $37.47 \mathrm{mg} \cdot \mathrm{Kg}^{-1}$ when PR was added by $1 \%$. On the other hands, the relation between $\mathrm{P}-\mathrm{NaHCO}_{3}$ fraction and added compost rate can be expressed by the next equation:

$P-\mathrm{NaCO}_{3}=107.58+42.5 \mathrm{Com}(\%)\left(R^{2}=0.85\right)$

This equation confirmed that, the increment rate in $\mathrm{P}-\mathrm{NaHCO}_{3}$ fraction was $42.5 \mathrm{mg} \cdot \mathrm{Kg}^{-1}$ when compost was added by $1 \%$.

The effect of incubation periods on $P$ $\mathrm{NaHCO}_{3}$ fraction can be expressed by the following equation:

$$
\begin{gathered}
\text { P. } \mathrm{NaCO}_{3}=218.13-8.5156 \text { In.Per } \\
\text { (months) }\left(\mathrm{R}^{2}=0.71\right)
\end{gathered}
$$

This equation indicate that, the decreasing rate of $\mathrm{P}^{-} \mathrm{NaHCO}_{3}$ was 8.52 mg. $\mathrm{Kg}^{-1}$ after one month incubation period.

The lowest value of $\mathrm{P}-\mathrm{NaOH}$ fraction was obtained in the soil in the control treatment of incubation and compost with addition of $1 \%$ RP. While the highest value of this fraction was obtained with the addition of $3 \%$ RP and $4 \%$ compost after 6 months incubation period. P-NaOH fraction represented $2.8 \%$ of the total phosphorous. The $\mathrm{P}-\mathrm{NaOH}$ fraction is related with unorganized oxy-hydroxide surfaces and crystalline Al- and Feoxides. Generally, this fraction is uneasy due to fluctuating redox conditions that cause mobilization or immobilization of $P$ from this fraction depending on the soil environment status (Jalali and Sajadi Tabar, 2011). It was observed that, the P$\mathrm{NaOH}$ values were the lowest fraction compared with the other phosphorus fractions. This could be due to the low levels of $\mathrm{Fe}$ and $\mathrm{Al}$ contents in Egyptian 
soils. Many previous studies showed that, the increase rates of added $P$ led to a significant increase in $\mathrm{Fe}$ - and $\mathrm{Al}$-bound fraction. The formation of this fraction could be attributed to the strong complexation of exchangeable $\mathrm{Al}$ and $\mathrm{Fe}$ with P (Von Wandruszka, 2006).

The increasing rates of $\mathrm{P}-\mathrm{NaOH}$ fraction can be deduced from the increasing rates any of the incubation periods, rock phosphate or compost.

The effect of RP on P-NaOH fraction can be expressed by the following equation:

$\mathrm{P}-\mathrm{NaOH}=70.85+4.03 \mathrm{PR} \%\left(R_{2}=0.76\right)$

This equation revealed that, increasing of phosphate rock rate by $1 \%$ led to increasing in $\mathrm{P}-\mathrm{NaOH}$ by $4.03 \mathrm{mg} \cdot \mathrm{Kg}^{-1}$. The following equation can be stated the relationship between $\mathrm{P}-\mathrm{NaOH}$ fraction and applied compost rate \%:

$\mathrm{P}-\mathrm{NaOH}=70.83+2.70$ Compost $\%\left(R^{2}=0.95\right)$

From this equation, It could be concluded that, the increase of applied compost rate by $1 \%$ led to increase in $\mathrm{P}$ $\mathrm{NaOH}$ by $2.70 \mathrm{mg} \cdot \mathrm{Kg}^{-1}$. Wright (2009) noticed that, the increase of organic matter applications resulted in important enhance of $\mathrm{Fe}-$ and $\mathrm{Al}$-bound $\mathrm{P}$ fraction. Also, it was reported that, inorganic fertilizers are one of the major inputs of $\mathrm{Fe}-$ and Al-bound $\mathrm{P}$ fraction in soil. Some investigators found that, the less labile inorganic and organic $P$ forms content was higher in the soil treated with compost than in that untreated (control) one. This could be attributed to the precipitation and fixation as well as synthesis of stable organic P (Garcia-Gil et al., 2000; Park et al., 2004; Shen et al., 2011).

The following linear equation can be explaining the effect of incubation periods on the extracted $\mathrm{P}-\mathrm{NaOH}$ fraction: $\mathrm{P}-\mathrm{NaOH}=71.00+1.74$ Incub.Per $\left(R^{2}=0.68\right)$
This equation indicated that, there was a positive relationship between incubation periods and $\mathrm{P}-\mathrm{NaOH}$ fraction. This fraction increased in soil by 1.74 mg.Kg-1 after one month incubation period.

The lowest value of $\mathrm{P}-\mathrm{HCl} / \mathrm{H}_{2} \mathrm{SO}_{4}$ fraction was found in the soil without RP addition having $2 \%$ added compost after 3 months incubation period. While the highest value was obtained in the soil treated with $1 \%$ RP and $4 \%$ compost after 6 months incubation period.

Most of $P$ applied to the soils is not taken up by plants but accumulates in them as various forms of inorganic and organic $\mathbf{P}$, that is commonly referred to the 'legacy P' (Stutter et al., 2012; Condron et al., 2005; Frossard et al., 2000).

The relation of RP $\%$ with $\mathrm{P}-\mathrm{HCl} / \mathrm{H}_{2} \mathrm{SO}_{4}$ fraction can be formulated by the following equation:

$\mathrm{P}-\mathrm{HCl} / \mathrm{H}_{2} \mathrm{SO}_{4}=96.6+568.45 \mathrm{PR} \%\left(\mathrm{R}^{2}=0.81\right)$

This equation revealed that, the increase of added RP by $1 \%$ led to increase in $\mathrm{P}-\mathrm{HCl} / \mathrm{H}_{2} \mathrm{SO}_{4}$ by $\mathbf{5 6 8 . 4 5}$ mg. $\mathrm{Kg}^{-1}$. On the other hands, the relation between $\mathrm{P}-\mathrm{HCl} / \mathrm{H}_{2} \mathrm{SO}_{4}$ fraction and added compost \% can be expressed with the next equation:

$$
\mathrm{P}-\mathrm{HCl} / \mathrm{H}_{2} \mathrm{SO}_{4}=1309.4+208.06 \mathrm{Com} \%
$$$$
\left(R^{2}=0.83\right)
$$

This equation confirmed that, the increment of $\mathrm{P}-\mathrm{HCl} / \mathrm{H}_{2} \mathrm{SO}_{4}$ fraction content was 208.06 mg.Kg-1 when compost applied with $1 \%$. On the one hand, the effect of incubation periods on $P$ $\mathrm{HCl} / \mathrm{H}_{2} \mathrm{SO}_{4}$ fraction can be expressed by the following equation:

$$
\mathrm{P}-\mathrm{HCl} / \mathrm{H}_{2} \mathrm{SO}_{4}=1521.1+68.139 \text { IncPe }\left(R^{2}=0.69\right)
$$

This equation establish that, the increasing rate of $\mathrm{P}-\mathrm{HCl} / \mathrm{H}_{2} \mathrm{SO}_{4}$ was 68.139 mg.Kg-1 after one month incubation period. 
The lowest P-digest (residual) fraction content was gotten in soil without RP, and $2 \%$ compost applications after 6 months incubation period. While the highest content was obtained in soil treated with $3 \%$ RP and $2 \%$ compost without incubation period. Generally, the results revealed that, the increase of RP or compost with increasing incubation period led to increase in residual $P$ fraction.

The effect of RP on residual $P$ fraction can be express with the next equation:

$$
\begin{aligned}
\text { Residual-P }\left(\mathrm{mg}^{\mathrm{Kg}} \mathrm{K}^{-1}\right)= & 672.13+121.17 \mathrm{PR} \% \\
& \left(\mathrm{R}^{2}=0.99\right)
\end{aligned}
$$

This equation revealed that, the increase of added RP by $1 \%$ led to increase in residual $P$ by $121.17 \mathrm{mg} . \mathrm{Kg}^{-1}$.

The relationship between residual $P$ fraction and applied \% compost can be expressed by equation:

$$
\text { Residual } \begin{aligned}
P\left(m g . K^{-1}\right) & =-40.017 X^{2}+161.86 X \\
& +776.76\left(R^{2}=0.99\right)
\end{aligned}
$$

It can mentioned that, the increase of applied compost up to $2 \%$ led to increase in residual $P$ by $940.4 \mathrm{mg} \cdot \mathrm{Kg}^{-1}$, then it decreased to 783.9 mg. $\mathrm{Kg}^{-1}$ with increasing compost application up to $4 \%$.

The effect of incubation periods on the residual phosphorous fraction can be expressed by following linear equation: Residual P (mg. $\left.\mathrm{Kg}^{-1}\right)=896.93-21.08$

$$
\text { Incub.Per }(R 2=0.99)
$$

From this equation, it can be concluded that, there was a negative relationship between incubation periods and residual $P$ fraction. The residual $P$ fraction was decreased by $21.08 \mathrm{mg} . \mathrm{Kg}-1$ after one month incubation period.

\section{REFERENCES}

Al-Oud, S. S. (2011). Improving phosphorus availability from phosphate rock in calcareous soils by amending with: organic acid, sulfur, and/or organic manure. Ozean Journal of Applied Sciences, 4(3): 227-235.

Ayaga, G., A. Todd and P. C. Brookes (2006). Enhanced biological cycling of phosphorus increases its availability to crops in low-input sub-Saharan farming systems. Soil Biology and Biochemistry, 38(1): 81-90.

Burt, Rebecca, Ed. (2004). Soil Survey Laboratory Methods Manual, Soil Survey Investigations Report No. 42, Version 4.0, USDA-NRCS, Lincoln, Nebraska.

Chen, Y., C. E. Clapp and H. Magen (2004). Mechanisms of plant growth stimulation by humic substances: The role of organo-iron complexes. Soil Science and Plant Nutrition, 50(7): 1089-1095.

Condron, L. M., B. L. Turner and B. J. Cade-Menun (2005). Chemistry and dynamics of soil organic phosphorus. Phosphorus: Agriculture and the Environment, 46: 87-121.

Frossard, E., L. M. Condron, A. Oberson, S. Sinaj and J. C. Fardeau (2000). Processes governing phosphorus availability in temperate soils. Journal of Environmental Quality, 29(1): 15-23. https://doi.org/10.2134/jeq2000.004724 25002900010003x

Fuentes, B., N. Bolan, R. Naidu and M. D. L. L. Mora (2006). Phosphorus in Organic Waste-Soil Systems. Revista de La Ciencia Del Suelo y Nutrición Vegetal, 6(2): 64-83. https://doi.org/10.4067/S071827912006000200006

Gao, L., H. Yang and J. M. Zhou (2005). Phosphorus release from sediments in Dianchi Lake under different environmental conditions. Soil (Chin), 37(2): 216-219.

Garcı-Gil, J. C., C. Plaza, P. Soler-Rovira and A. Polo (2000). Long-term effects of municipal solid waste compost application on soil enzyme activities 
and microbial biomass. Soil Biology and Biochemistry, 32(13): 1907-1913.

Gomez, K. A. and A. A. Gomez (1984). Statistical procedures for agricultural research. John Wiley \& Sons.

Ibrahim, M., A. U. Hassan, M. Iqbal and E. E. Valeem (2008). Response of wheat growth and yield to various levels of compost and organic manure. Pakistan Journal of Botany, 40(5): 2135-2141.

Jalali, M. and Tabar, Samaneh S. (2011). Chemical fractionation of phosphorus in calcareous soils of Hamedan, western Iran under different land use. Journal of Plant Nutrition and Soil Science, 174(4): 523-531.

Khan, K. S. and R. G. Joergensen (2009). Changes in microbial biomass and $P$ fractions in biogenic household waste compost amended with inorganic $P$ fertilizers. Bioresource Technology, 100(1): 303-309.

https://doi.org/10.1016/j.biortech.2008. 06.002

Liu, P., J. Bai, Q. Ding, H. Shao, H. Gao and R. Xiao (2012). Effects of water level and salinity on TN and TP contents in marsh soils of the Yellow River Delta, China. Clean-Soil, Air, Water, 40(10): 1118-1124.

McCullum, R. E. (1996). Soil phosphorus and potassium. The Nature and Properties of Soils, 2nd Ed. NC Brady and RR Weil (Eds.). Prentice-Hall International, Inc, 445-487.

Park, B., J.H. Ahn, J. Kim and S. Hwang (2004). Use of microwave pretreatment for enhanced anaerobiosis of secondary sludge. Water Science and Technology, 50(9): 17-23.

Qian, P. and J. J. Schoenau (2000). Fractionation of $P$ in soil as influenced by a single addition of liquid swine manure. Canadian Journal of Soil Science, 80(4): 561-566.

Rajan, S. S. S., O'connor, M. B., and A. G.
Sinclair (1994). Partially acidulated phosphate rocks: Controlled release phosphorus fertilizers for more sustainable agriculture. 69-78.

Scherer, H. and S. Sharma (2002). Phosphorus fractions and phosphorus delivery potential of a luvisol derived from loess amended with organic materials. Biology and Fertility of Soils, 35(6): 414-419.

Shaheen, S. M., C. D. Tsadilas and S. Stamatiadis (2007). Inorganic phosphorus forms in some entisols and aridisols of Egypt. Geoderma, 142(1-2): 217-225. https://doi.org/10.1016/j.geoderma.200 7.08.013

Shen, J., L. Yuan, J. Zhang, H. Li, Z. Bai, X. Chen, W. Zhang and F. Zhang (2011). Phosphorus dynamics: From soil to plant. Plant Physiology, 156(3): 9971005.

https://doi.org/10.1104/pp.111.175232

Stutter, M. I., C. A. Shand, T. S. George, M. S. A. Blackwell, R. Bol, R. L. MacKay, A. E. Richardson, L. M. Condron, B. L. Turner and P. M. Haygarth (2012). Recovering phosphorus from soil: A root solution? Environmental Science and Technology, 46(4): 1977-1978. https://doi.org/10.1021/es2044745

Sui, Y., M. L. Thompson and C. Shang (1999). Fractionation of phosphorus in a Mollisol amended with biosolids. Soil Science Society of America Journal, 63(5): $\quad$ 1174-1180. https://doi.org/10.2136/sssaj1999.6351 174x

Von Wandruszka, R. (2006). Phosphorus retention in calcareous soils and the effect of organic matter on its mobility. Geochemical Transactions, 7(1): 1-8.

Wright, A. L. (2009). Phosphorus sequestration in soil aggregates after long-term tillage and cropping. Soil and Tillage Research, 103(2): 406-411. 
تأثير اضافة الفوسفات الصخري والكمبوست على صور فسفور التربة بعد فترات تحضين مختلفة

صلاح عبد المجيد رضوان(")، محمد محمد حمادة شلبى")، وائل عبد الرحمن ندا(1)،

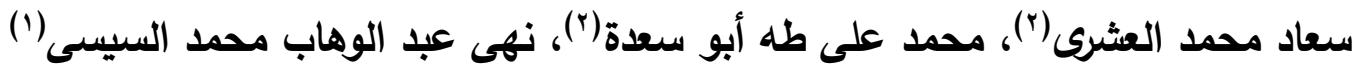
(1) - كلية الززاعة جامعة المنوفية

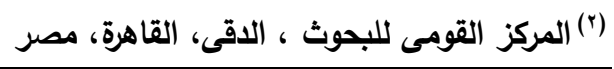

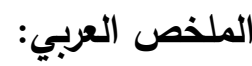

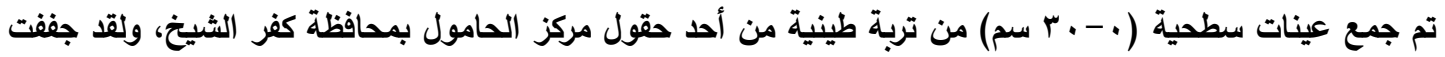

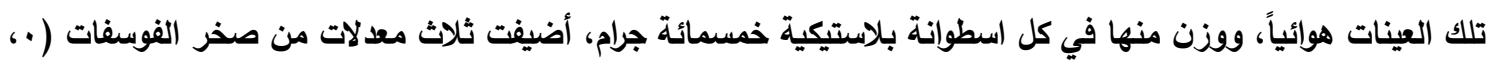

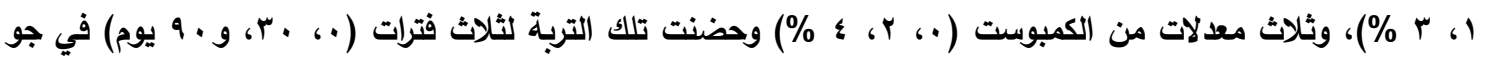

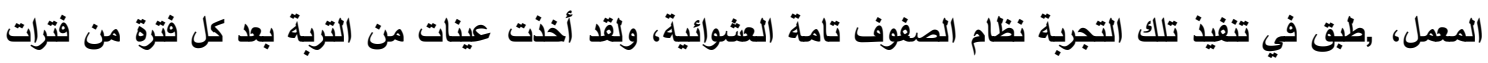

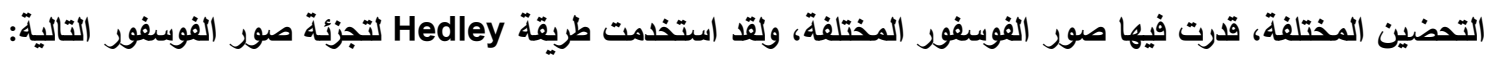

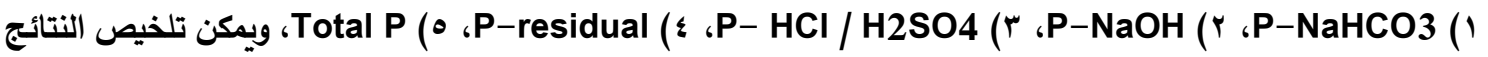
فيما يلي:

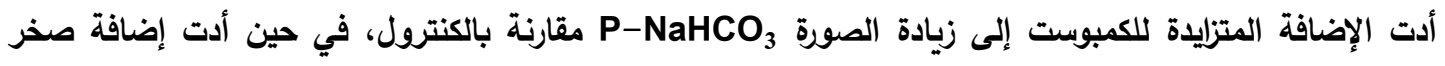

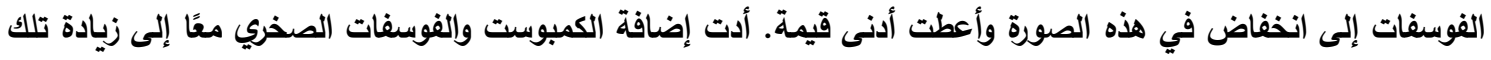
الصورة P-NaHCO

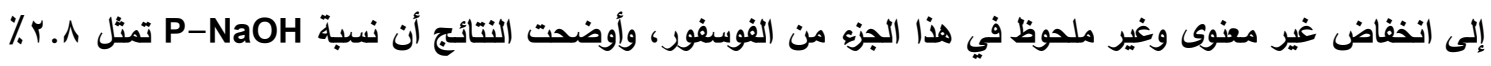

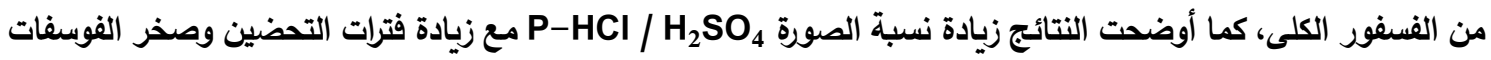
والكمبوست. كما أظهرت النتائج انخفاض نسبة الفوسفور المتبقى مع زيادة فترة التحضين.

كلية الزراعة - جامعة المنوفية

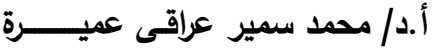

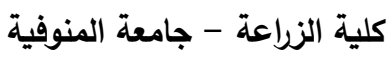

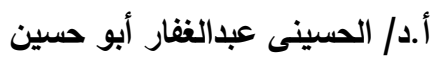


S. A. Radwan, et al., 